\title{
CORRELATIVE SCANNING AND TRANSMISSION ELECTRON MICROSCOPIC STUDY ON THE EPENDYMAL SURFACE OF CEBUS APELLA
}

\author{
CLAUDIO A. FERRAZ DE CARVALHO * \\ II-SEI WATANABE* \\ ROMEU RODRIGUES DE SOUZA*
}

In a previous paper we have analysed the surface of the whole brain ventricular system (BVS) of the Bradypus tridactylus, a Brazilian wild animal (Ferraz de Carvalho and col.7). Although the ependymal lining has been one of the most biological systems studied with the scanning electron microscope (Mitchell14), very few findings are available concerning those animals, even at the light or transmission electron microscopy (Ferraz de Carvalho and col,4,5,6). With the same pourpose, we consider in this work the Cebus apella (turfted capuchin monkey), another wild Brazilian species.

\section{MATERIAL AND METHODS}

Three specimens of Cebus apella had their brains removed under nembutal anesthesia, cut in slices $5 \mathrm{~mm}$ thick along frontal planes and immersed in modified Karnovsky's solution (11) fixative containing $2 \%$ paraformaldehyde, in $0.1 \mathrm{M}$ sodium cacodylate buffer (pH7.4), for about 48 hs. The slices were then reduced to 14 parts for each animal, in order to provide specimens of suitable size for the scanning electron microscope (SEM). These specimens were dehydrated in ethanol, $\mathrm{CO} 2$ critical polnt dried and mounted in metal stubs with conductive material. Coating was carried out in a carbon-gold evaporator, and analysed in a - JEOL JSM-P15 scanning electron microscope of the Laboratory of Electron Microscopy of the Chemical Institute of the «Universidade Estadual Paulista» (Araraquara, São Paulo, Brazil).

After observation at the SEM, selected fragments of the antero-lateral part of the lateral ventricle roof were treated with propylene oxide, embedded in araldite and sectioned perpendicularly to the ependymal surface. One $\mu^{\mathbf{m}}$ thick sections for light microscopy were stained with toluidine blue - Azur II (1:1), being the thin sections for transmission electron microscopy (TEM) stained with lead citrate and uranyl acetate. All sections were made with and LKB Ultratome. (FAPESP grant 70/1445). The EM was a Philips-201 of the Heart Institute at the Medical School of the São Paulo University.

\footnotetext{
* Department of Anatomy, Biomedical Sciences Institute, São Paulo University.
} 


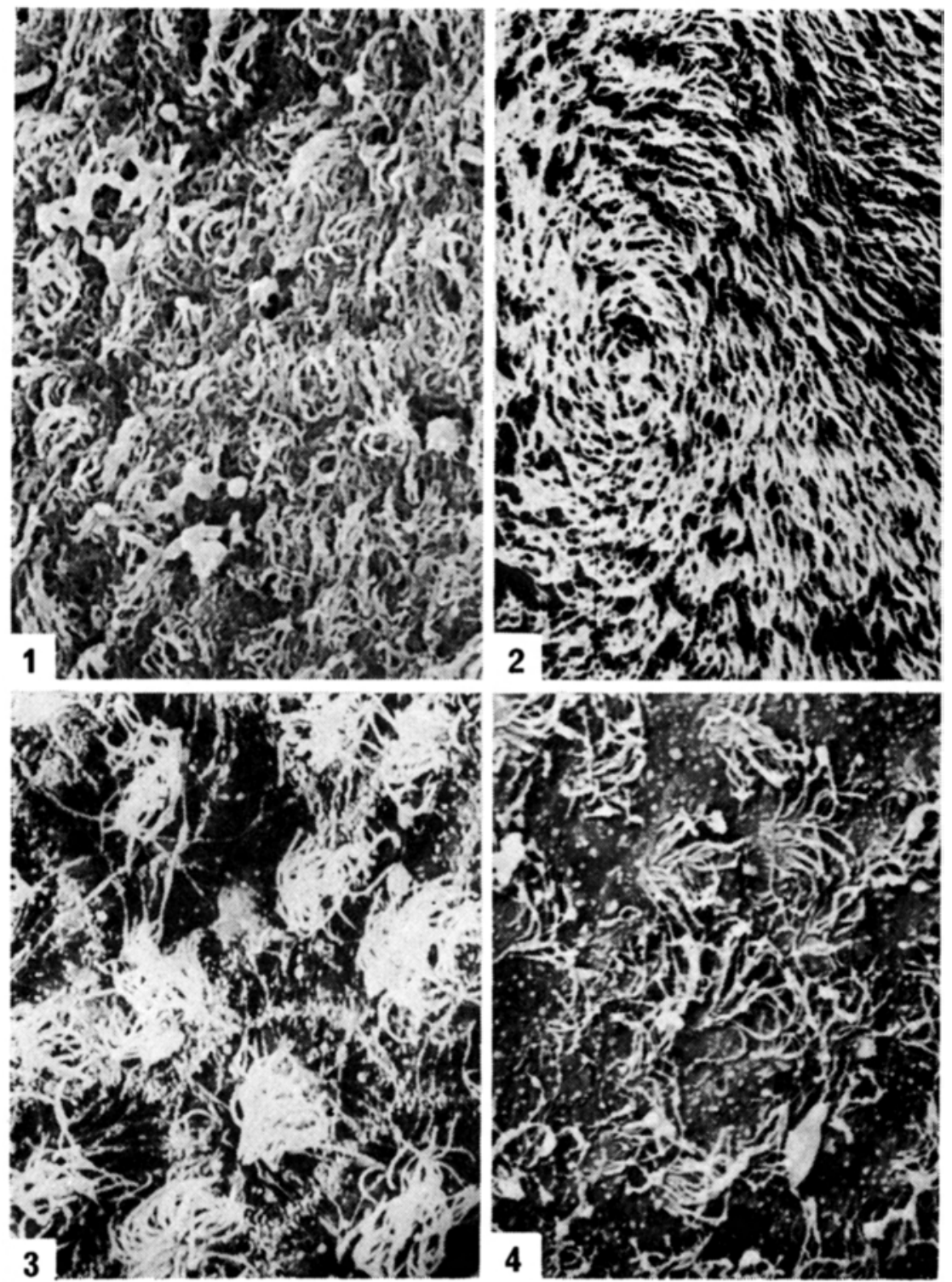

Fig. 1-4 - Scanning electron micrographs of different ependymal regions of Cebus apella (see text): fig. 1 x 2,$500 ;$ fig. $2 \times 1,250 ;$ fig. $3 \times 2,750 ;$ fig. $4 \times 2,500$. 

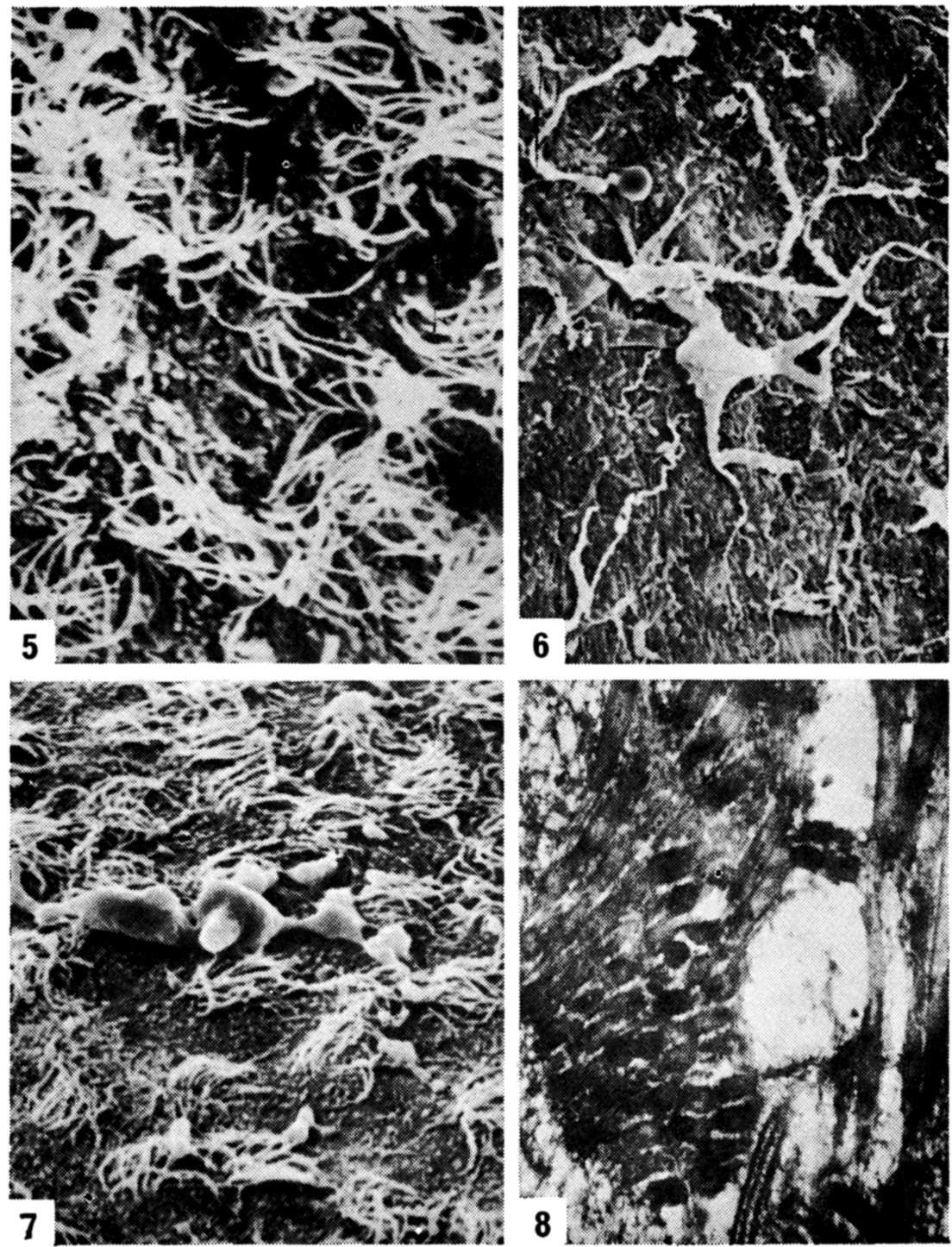

Fig. 5-7 - Scanning electron micrographs of different ependymal regions of Cebus apella (see text): fig. 5 x3,300; fig. 6 x1,250; fig. 7 x2,500. Fig. 8 Transmission electron micrograph of a SEM preparation of Cebus apella (antero-lateral part of the lateral ventricle roof): $\mathrm{x} 30,000$. 


\section{RESULTS}

A surprisingly great number of long cilia was observed in the whole ventricular surface of the encephaion of the Cebus, being particularly numerous in the lateral and posterior parts of the lateral ventricles (LV) close to the junction of the inferior and posterior horns (Fig. 1). A clear ordination of the cilia system was not observed, except in a small stretch of the posterior and superior aspects of the $\mathrm{LV}$ and in the superior half of the IV ventricle, where a «swirl» like disposition was present (Fig. 2). Only in few areas we observed the surface of the ependymal cells and their boundaries because the great amount of cilia. These cells were generally poligonal with peripheric microvilli and a tuft of cilia in their central portion. This disposition was a characteristic of the posterior and superior parts of the LV (Fig. 3). Similar aspects were also observed in the roof of the IV ventricle, anterior part of the III ventricle, under the corpus callosum frontally to the interventricular foramen (IVF), in the anterior extremity and in parts of the $\mathrm{LV}$, close to the fornix, being the cilia longer in these two latter zones.

In the roof of the IV ventricle at the level of the vermis, and in parts of the floor of the same ventricle, there were also cilia in a small (Fig. 4) and in a great (Fig. 5) quantity, respectively, with microprojections of different sizes, spread along the cell surface or still concentrated at the cell periphery. Filamentar structures with more or less conspicuous bulgings along their trajectories and voluminous and irregular bodies were observed, close to the ependymal surface (supraependymal structures). Sometimes small roots were seen between these structures and the ventricular surface, going apparently into the subependymal layer among the intercellular junctions. The supraependymal structures were clearly visible in the posterior and superior parts of the LV (Fig. 3) and also close to the fornix, under the corpus callosum and floor of the IV ventricle.

Only close to the fornix, posteriorly to the IVF we found a zone without cilia or microvilli, with a great amount of supraependymal structures. Nevertheless, in such areas the ventricular surface of these cells, shows numerous small and irregular folds (Fig. 6).

Blebs linked to the cell surface were also present in areas with smaller amounts of cilia (Fig. 5). They are greater than the microprojections. In the antero-lateral parts of LV's roof close to IVF, a small amount of large and bizarre projections were observed (Fig. 7).

As we have described for the Bradypus tridactylus (Ferraz de Carvalho and col. 7) such bulgings were formed by a flat-cell monolayered ependymal lining which covers spaces, opened into the ventricular lumen filled by many long cilia (Fig. 8). The bulgings however were smooth and smaller in comparison with those of the B. tridactylus. 


\section{COMMENTS}

The role played by the great amount of cilia of the BVS surface of Cebus apella in the circulation of biologically active substances towards certain regions of the encephalon and the participation of the microvilli in the absorption, production of an ultrafiltrate of blood substances to the cerebrospinal fluid (CSF) and in the secretion have already been discussed in a previous paper (Ferraz de Carvalho et al.7).

Bleb-like cell protrusions, like those of the $B$. tridactylus were seldom observed in the $C$. apella. These structures, reported to occur mainly in the III ventricle by many authors studying different species (Pontenagel18; Takeichi21; Nakai15; Marquet and col.13; Schechter and Weiner20; Hetze18,9; Weindl and Schinko ${ }^{22}$ ), have also been considered as a morphological expression of a micro-apocrine secretion process.

We found although not frequently cells with microvilli located mainly on the cell periphery. These cells could possibly be related to a higher absorption degree of the ependymal intercellular spaces.

The functional significance of the supraependymal structures similar to those of the $B$. tridactylus i. e., fiber-like plexus, with or without bulb bulgings is controversial (Ferraz de Carvalho et al.7).

Though many of these structures are said to be of nervous nature, diverging opinions arise concerning their functions. Acoording to Agduhr ${ }^{1}$, Pesonen 17 and Leonhardt12, for instance, these structures play a receptor role, while for Dierickx ${ }^{3}$ they act as osmoreceptors. Others (Bargmann and Scharrer2; Pensa16; Ito ${ }^{10}$, Rodrigues 19 ) admit the participation of such structures in CSF secretion processes.

\section{SUMMARY}

Topographical variations of the ependymal surface of the whole brain ventricular system of Cebus apella, a wild Brazilian species, were studied at the scanning electron microscope after $\mathrm{CO} 2$ critical point drying and carbon-gold coating. Certain selected areas were also studied at the transmission electron microscope, following standard technical procedures. We observed distinct patterns in the distribution of cilia, microvilli, other cell projections, and the so called supraependymal structures. Based on the morphological findings, functional considerations are made.

\section{RESUMO}

Estudo correlativo à microscopia eletrônica de varredura e de transmissão da superficie do epêndima do Cebus apella.

Variaçōes topográficas da superfície ependimária de todo o sistema ventricular encefálico do Cebus apella, uma espécie silvestre brasileira, foram estudadas mediante microscopia eletrônica de varredura, após secagem pelo método do ponto 
critico do $\mathrm{CO} 2$ e metalização pelo ouro-carbono. Determinadas áreas foram também estudadas no microscópio eletrônico de transmissão, após os procedimentos técnicos usuais. Observamos distintos padrões na distribuição de cílios, microvilosidades, e outras projeções celulares, além das assim chamadas estruturas supraependimárias. São feitas consideraçōes morfofuncionais, baseadas nos achados morfológicos.

\section{REFERENCES}

1. AGDUHR, E. - Ueber ein zentrales Sinneorgan (?) bei den Vertebraten. Z. anat. Entwicks-Gesch. 66:223, 1922.

2. BARgMANN, W. \& SCHARRER, E. - The site of origin of the hormones of the posterior pituitary. Amer. Scientist $39: 245,1951$.

3. DIERICKX, K. - The dendrites of the preoptic neurosecretory nucleus of Rana temporaria and the osmoreceptors. Arch. int. Pharmacodyn. 140:708, 1962.

4. FerRaz DE CaRvalho, C.A.; Costacurta, L. \& CaRvalho Filho, J.R. - Histological and histochemical study on the ependyma of Bradypus tridactylus. Acta. anat. (Basel) 92-424, 1975.

5. FERRAZ DE CARVALHO, C.A. \& COSTACURTA, L. - (A) Ultrastructural study on topographical variations of the ependyma in Bradypus tridactylus. Acta. anat. (Basel) 94:369, 1976.

6. FERraz DE CARvalho, C.A.; KöNIG JR., B. \& RODRIGUeS JR., A.J. - (B) Ultrastructural study on the relations among nerve elements and ependymal cells of the Bradypus tridactylus. Rev. bras. Pesq. méd. biol. 9:137, 1976.

7. FERraz DE CARVAlho, C.A.; Chagas, C.F.; SIllya, C.F. \& ReIS, F.P. Correlative scanning and transmission electron microscopic study on the ependymal surface of Bradypus tridactylus. Arq. Neuro-Psiquiat. (São Paulo) 41:64, 1983.

8. HETZEL, W. - Ependymal structure of the anterior and inferior horn of the lateral ventricle of the rabbit brain: scanning electr. Microse. 2:129, 1978.

9. HETZEL, W. - The posterior horn and collateral trigone of the lateral ventricle of the monkey brain (Macaca speziona): a scanning electron microscopic study. Cell Tiss. Res. 186:161, 1978.

10. ITO, H. - The receptor in the reptilian brain. J. Hirnforsch. 7:943, 1965.

11. KARNOVSKY, M.J. - A formaldehyde-gluteraldehyde fixative of high osmolartty for use in electron microscopy. J. Cell Biol. 27:137, 1965.

12. LEONHARDT, H. - Intraventrikuläre markhaltige Nervenfasern nahe der Apertura Iateralis ventriculi quarti des Kanninchengehirns. Z. Zellforsch. 84:1, 1968.

13. MARQUET, E.; SOBEL, H.J.; SCHWARZ, E. \& WEISS, M. - Secretion by ependymal cells of the neurohypophysis and saccus vasculosus of Polyypterus ornatipinnis (Ostejchthyes). J. Morph. 137:111, 1972.

14. MITCHELL, J.A. - Scanning electron microscopy of brain ventricular surfaces: a bibliography. Scanning electr. Microsc. 3:475, 1980 .

15. NAKAI, Y. - Fine structure and its functional properties of the ependymal cell in the frog median eminence. Z. Zellforsch. 122:15, 1971.

16. PENSA, A. - Della esistenza di fibre nervose aventi speciali rapporti col ependyma. Boll. Soc. méd. chir. (Pavia), 1903. (Apud AGDUHR. E. 1922). 
17. PESONEN, N. - Ueber die intraependymalen Nervenelemente. Anat. Anz. 90: $193,1940$.

18. PONTENAGEL, M. - Elektronenmikroskopische Untersuchungen am Ependym, der Plexus chorioidei bei Rana esculenta und Rana fusca (Roesel). Z. mik. anat. Forsch. 68:371, 1962.

19. RODRIGUES, E.M. - Neurosecretory system of the toad Bufo arenarum Hensel and its changes during inanition. Gen. comp. Endocr. 4:684, 1964.

20. SCHECHTER, J. \& WEINER, R. - Ultrastructural changes in the ependymal lining of the median eminence following the intraventricular administration of catecholamine. Anat. Rec. 172:643, 1972.

21. TAKEICHI, M. - The fine structure of ependymal cells. II. An electron microscopic study of the soft-shelled turtle paraventricular organ, with special reference to the first structure of ependymal cells and so called albuminous substance. $\mathrm{Z}$. Zellforsch. 76:471, 1967.

22. WEINDL, A. \& SCHINKO, I. - The ventricular system of the opossum brain. Scanning electr. Microsc. 2:861, 1978.

Departamento de Anatomia, Bloco-so, Instituto de Ciencias Biomédicas, Umiversidade de São Paulo - Caixa Postal, 4365 - 01000 - São Paulo, SP - Brasil. 